\title{
Application of a domicile-based exercise program for shoulder rehabilitation after breast cancer surgery
}

\author{
Eliana Louzada Petito ${ }^{1}$ \\ Afonso Celso Pinto Nazário² \\ Simone Elias Martinelli ${ }^{3}$ \\ Gil Facina ${ }^{4}$ \\ Maria Gaby Rivero De Gutiérrez ${ }^{5}$
}

The aim of this study was to evaluate the effectiveness of an exercise program for the recuperation of the range of motion (ROM) of the shoulder. This is a quasi-experimental study developed at the Mastology Outpatient Clinic of the Federal University of São Paulo - Brazil, from August 2006 to June 2008, with 64 breast cancer patients undergoing surgery. The intervention consisted of: preoperative evaluation of the ROM, verbal and written guidance, demonstration and implementation of the exercises and revaluation at the outpatient follow-up appointments until the $105^{\text {th }}$ postoperative day (PO). From the $7^{\text {th }} \mathrm{PO}$ a significant increase was observed in the ROM, which continued until the $105^{\text {th }}$ PO. The minimum time for recovery was 105 days for the women undergoing mastectomy, and 75 days for those undergoing quadrantectomy. There was satisfactory adherence of $78.6 \%$ of the women. The domicile program was effective for the recovery of ROM in the study population, benefiting women who can not attend a presential program.

Descriptors: Breast Neoplasm; Rehabilitation; Physiotherapy; Postoperative Care; Oncologic Nursing.

\footnotetext{
${ }^{1}$ Physical Therapist, Ph.D. in Sciences. E-mail: lica.sp@ig.com.br.

2 Physician, Free Lecture, Associate Professor, Departamento de Ginecologia, Universidade Federal de São Paulo, SP, Brazil. E-mail: nazarioafonso@hotmail.com.

${ }_{3}$ Physician, Post-Doctoral in Clinical Radiology, Coordinator of the Casa da Mama, Universidade Federal de São Paulo, SP, Brazil. E-mail: simoneelias3@yahoo.com.br.

${ }^{4}$ Physician, Doctor in Mastology, Adjunct Professor, Departamento de Ginecologia, Universidade Federal de São Paulo, SP, Brazil. E-mail: gilfacina@terra.com.br.

${ }^{5}$ RN, Free Lecturer, Associate Professor, Escola de Enfermagem, Universidade Federal de São Paulo, SP, Brazil. E-mail: gaby.gutierrez@unifesp.br.
}

Corresponding Author:

Maria Gaby Rivero de Gutiérrez

Universidade Federal de São Paulo. Escola Paulista de Enfermagem

Rua Napoleão de Barros, 754 Sala 212

Vila Clementino

CEP 04020-002 São Paulo, SP, Brasil

E-mail: gaby.gutierrez@unifesp.br 


\section{Aplicação de programa de exercícios domiciliares na reabilitação do ombro pós-cirurgia por câncer de mama}

O objetivo desta pesquisa foi avaliar a efetividade de um programa de exercícios para recuperação da amplitude de movimento (ADM) do ombro. Foi usado o método experimental, e o estudo foi desenvolvido no Ambulatório de Mastologia da Universidade Federal de São Paulo, Brasil, de agosto de 2006 a junho de 2008, com 64 mulheres com câncer de mama, submetidas à cirurgia. A intervenção constou de: avaliação préoperatória da ADM, orientação verbal e escrita, demonstração e execução dos exercícios e reavaliações nos retornos ambulatoriais até o $105^{\circ}$ dia de pós-operatório (PO). Os resultados mostraram, a partir do 70PO, acréscimo significante e contínuo na ADM, até o $105^{\circ}$ PO. O tempo mínimo para recuperação foi de 105 dias para as mulheres mastectomizadas, e de 75 dias para aquelas submetidas à quadrantectomia. Houve adesão satisfatória de $78,6 \%$ das mulheres. Conclui-se que o programa domiciliar se mostrou efetivo para a recuperação da ADM na população estudada, beneficiando mulheres que não poderiam frequentar um programa presencial.

Descritores: Neoplasias da Mama; Reabilitação; Fisioterapia; Cuidados Pós-Operatórios; Enfermagem Oncológica.

\section{Aplicación de un programa de ejercicios domiciliarios en la rehabilitación del hombro después de cirugía por cáncer de mama}

El objetivo de este estudio fue evaluar la efectividad de un programa de ejercicios para recuperación de la amplitud de movimientos (ADM) del hombro. Se trata de una investigación cuasi experimental desarrollada en el Ambulatorio de Mastología de la Universidad Federal de Sao Paulo, en Brasil, de agosto de 2006 a junio de 2008, con 64 mujeres con cáncer de mama, sometidas a cirugía. La intervención constó de: evaluación preoperatoria (ADM), orientación verbal y escrita, demostración y ejecución de los ejercicios y reevaluaciones en los retornos al ambulatorio, hasta el $105^{\circ}$ día de posoperatorio (PO). Se constató un aumento significativo y continuo de la ADM, del 70PO hasta el 1050PO. El tiempo mínimo para la recuperación fue 105 días para las mujeres mastectomizadas y 75 para las sometidas a cuadrantectomía. Hubo adhesión satisfactoria de $78,6 \%$. Se concluye que el programa domiciliario se mostro efectivo para la recuperación de la ADM en esa población, beneficiando mujeres que no podrían frecuentar un programa presencial.

Descriptores: Neoplasias de la Mama; Rehabilitación; Fisioterapia; Cuidados Posoperatorios; Enfermería Oncológica.

\section{Introduction}

Breast cancer is the second most frequent type of cancer worldwide and the most common cause of death

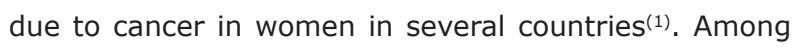
the therapeutic modalities surgery is highlighted, and the greater its delay, the greater the likelihood of postoperative complications. The limitation of the range of motion (ROM) of the shoulder is considered one of the major postoperative complications of the treatment of breast cancer, and is accompanied by impairment and decrease of the upper limb function ${ }^{(2-7)}$. The shoulder is subject to the rapid installation of stiffness and muscle atrophy after breast cancer surgery, with the flexion and abduction movements the most affected ${ }^{(7-8)}$. The prolonged immobilization caused by fear and/or pain, as well as the type of surgery, the incision size, the performance of axillary lymphadenectomy, long thoracic nerve trauma or muscle spasm throughout the cervical region, arising from the muscular defense reaction, are factors that cause women to have a tendency toward little movement of the upper $\operatorname{limb}^{(9-10)}$. To decrease the 
incidence of these complications, studies highlight that the performance of exercises immediately after surgery gives positive results, both in the physical and the psychological areas, since it provides conditions for the woman to return to their activities of daily living (ADLs) within a shorter period of time ${ }^{(4,9,11)}$.

Among the studies consulted, the majority described rehabilitation programs in which women undergoing surgery performed exercise in the physiotherapy or rehabilitation service of the hospital, often two to three times a week, complemented at home, with the help of manuals and/or educative videos $^{(2,5-6,12-15)}$. Few studies, however, report on exercise performed exclusively in the domicile(2-3,13). In common, all the programs present a preoperative evaluation and a gradual progression in the exercises, starting early, from the $1^{\text {st }}$ postoperative day $(\mathrm{PO})^{(2-3,6,9,12,14-15)}$. Only one study recommends the initiation of the exercise program after removal of the drain(13), and another later, after the $6^{\text {th }}$ or $26^{\text {th }}$ postoperative week $^{(5)}$. Some points, however, are controversial, with there being no consensus on how much and which exercises are best suited to promote the functional recuperation of the shoulder after surgery. Emphasis is given to stretching of the cervical region and to the active movement of the upper limb (flexion, extension, abduction and rotation of the shoulder), however, only three studies described, as well as the type, the number of exercises proposed for the rehabilitation program, with a variation in these of between 13 and 19(3,6,14). Furthermore, the period of postoperative monitoring varied, with two weeks to two years being encountered(2-3,5-6,12-16). It should be noted that to achieve the goals of a rehabilitation program, the patient needs to adhere to the treatment, as well as to be encouraged and supported by the family and the healthcare team.

The knowledge of the benefits, the low level of difficulty of the exercises, the social reinforcement, the trust in the leaders of the program, and the possibility of the realization of this outside specialized centers, after prior guidance, are determinant factors to facilitate adherence to the exercise programs(17-20). However, a lack of time, domestic chores and the collateral effects of the antineoplastic treatment are barriers to following the exercises ${ }^{(17,20)}$. It should be noted that for the rehabilitation of the shoulder in women undergoing breast cancer surgery to be effective, a full or partial recovery of ROM should be promoted. Some authors ${ }^{(6,15)}$ describe as acceptable a deficit in the recovery of the ROM between 10 and $15 \%$ of the value considered normal for each movement of the shoulder (flexion $=180^{\circ}$; abduction $=180^{\circ}$; extension $=45^{\circ(21)}$, since this decrease does not affect the functionality of the upper limb to perform ADLs. In addition to the functional limitations, women with breast cancer are also exposed to an impact in their quality of life, with respect to psychosocial adjustments, due to different stressors, including the change in self-image, sense of self-sufficiency, fear of the progression of the condition and anxiety regarding returning to the professional activity ${ }^{(22)}$. In this study, however, emphasis was given to the functionality of the upper limb.

Consequently, it can be seen that there is no consensus regarding the ideal time for starting the exercises, whether early, in the first days after surgery, or after removal of the drain, nor how long it should be performed for. Another aspect that is not sufficiently clear is the number and type of exercises needed to promote recuperation of the ROM of the shoulder ipsilateral to the surgery. Even knowing the benefits of formally implementing an exercise program and postoperative monitoring, in Brazil, not all the public health services that treat women with breast cancer offer this service, and when it is available, the socioeconomic characteristics of the population attended in these institutions constitute a limiting factor for their attendance at outpatient sessions. Given these considerations, the exercise program tested was performed in an extramural way, after professional guidance, monitoring and encouragement to carry out the exercises in the domicile, and complemented by an explanatory manual consisting of a set of nine exercises selected from a literature review and validated by specialists in the field of Mastology rehabilitation(23).

Thus, the general aim of this study was to evaluate the effectiveness of an exercise program, initiated early and performed in the domicile, to recover the ROM of the limb ipsilateral to the surgery of women undergoing quadrantectomy or mastectomy. The specific objectives were: to verify the time required for the recuperation of the flexion, extension and abduction movements of the joint, according to the type of surgery and the adherence of the patients to the program.

\section{Method}

This is a quasi-experimental, before and after study ${ }^{(24)}$, held in the Mastology Outpatient Clinic of the Gynecology Department of the Federal University of São Paulo, from August 2006 to June 2008, after approval of the project by the Research Ethics Committee of the University (CEP No. 1488/05). The sample size calculation was performed using the programs NCSS 
2004 and PASS 2002 with a significance level of 5\%, a power of $90 \%$ and an effect size of 1.15 between the evaluations. A pilot study with 29 patients suggested a minimum total of 60 patients. In the period studied, the population undergoing oncological breast surgery at the Mastology Outpatient Clinic of the São Paulo Hospital consisted of 185 women. Of this total, 94 did not fulfill the inclusion criteria. The inclusion criteria were: indication of quadrantectomy or mastectomy for breast neoplasm, with or without axillary lymphadenectomy, understanding and agreement to participate in the study, with signing of the Terms of Free Prior Informed Consent (TFPIC), preoperative evaluation of the ROM and a mental condition sufficient to comprehend the guidance. The exclusion criteria were: limitation of the ROM of the shoulder ipsilateral to the surgery greater than $10 \%$ of the normal range and immediate performance of breast reconstruction.

A total of 22 patients (24.1\%) were considered lost to monitoring that did not attend the penultimate or last evaluation ( $75^{\text {th }}$ or $105^{\text {th }} \mathrm{PO}$ ), preventing the measurement of the final recuperation of the ROM, and five women who, during the monitoring, required reoperation. Therefore, 64 women completed the minimum monitoring of 75 days. It should be noted that the grouping of the patients into two groups was due to the fact that among the non-conservative surgeries, modified radical mastectomy was prevalent (37/43 - 86.0\%), followed by simple mastectomy (4/43 to $9.3 \%$ ) and finally, by radical mastectomy (2/43 - 4.7\%). Regarding lymphadenectomy, in this group, 38 women (88.4\%) underwent axillary manipulation. Therefore, it was decided to group them into one group of women undergoing mastectomy and another group of women undergoing conservative surgery (quadrantectomy).

The exercise program tested consisted of a series of nine exercises with 10 repetitions of each, performed extramurally, after guidance during the hospitalization, with further guidance at the outpatient follow-up appointment ${ }^{(23)}$. The exercises were initiated on the $1^{\text {st }}$ $\mathrm{PO}$, even with the presence of the continuous suction drain, after understanding the study and the signature of the TFPIC by the patients who agreed to participate. The reevaluations occurred on the $7^{\text {th }}, 14^{\text {th }}, 45^{\text {th }}, 75^{\text {th }}$ and $105^{\text {th }}$ PO. All the guidance, as well as evaluations of the ROM and of the adherence, were performed by the same instructor. To define the follow-up period, an analysis of the average time described in the literature was performed, which showed that the predominant period to achieve satisfactory results with regard to functional


this reason, in this study, the follow-up period extended from the preoperative period until the $75^{\text {th }}$ or $105^{\text {th }} \mathrm{PO}$, as shown in Figure 1.

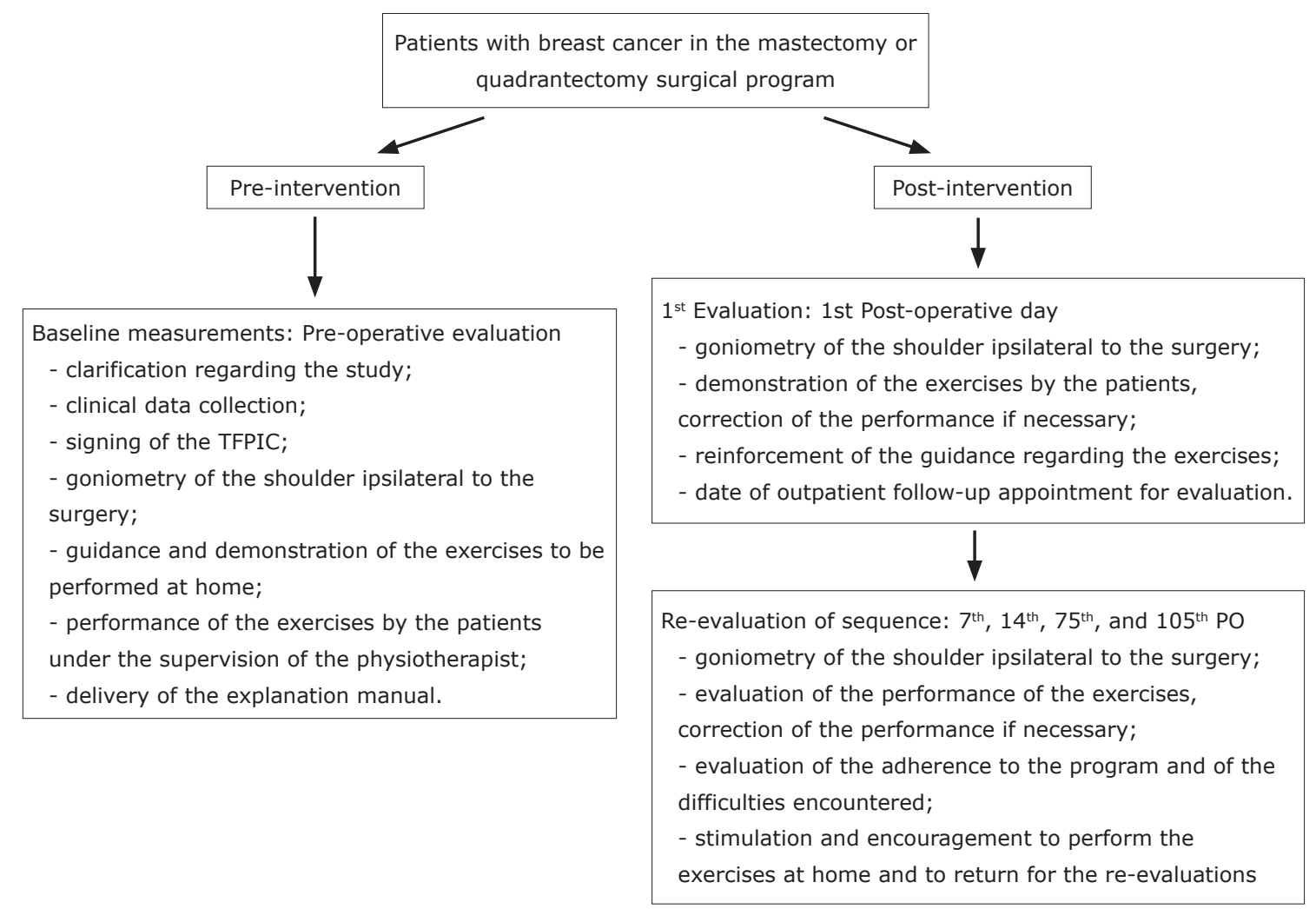

Figure 1 - Planning of the data collection procedure. São Paulo, SP, Brazil, 2006 
The pre-intervention data collection for the evaluation of the patients occurred in the preoperative period and included identification, clinical and surgical data, as well as measures of flexion, extension and abduction of the shoulder ipsilateral to the surgery, using the goniometer (transparent plastic Goniometer CARCI Brazil). To evaluate these movements, the positioning of the patient, sitting with back support, maintaining a good postural alignment, with the shoulder region uncovered, was standardized. The extension was measured with the elbow flexed, and in all the movements compensation with the trunk, elevation of the scapula or combined movements were avoided(21). At this time, the exercises were also explained and demonstrated by the instructor and repeated by the patients, with the guidance manual prepared for consultation in the domicile also delivered.

The initial ROM of the exercises was free, according to the feeling of discomfort of the patient, supported by a previous study ${ }^{(15)}$, which found no statistically significant difference in the incidence of complications in programs with free ROM from the start or ROM limited to $90^{\circ}$ until the removal of the drain. The proposed exercises were validated in a previous study ${ }^{(23)}$, and consisted of two phases: PHASE 1 (from the $1^{\text {st }}$ PO until removal of the drain - exercises performed up to the individual limit of the patient) - two stretches for the cervical region, two exercises for movement of the scapular girdle, one for shoulder flexion and one for extension beyond the midline; PHASE 2 (added to those performed in Phase 1, after the removal of the drain until the $105^{\text {th }} \mathrm{PO}$ ) - one exercise for flexion and two for abduction of the shoulder.

On the $1^{\text {st }} \mathrm{PO}$, in the ward, the women performed the six initial exercises contained in the manual, under the supervision of the researcher, and were encouraged to perform them every day, in the domicile, after hospital discharge, until the first outpatient follow-up appointment ( $7^{\text {th }}$ to $10^{\text {th }} \mathrm{PO}$ ). After removal of the drain, they were given guidance regarding the performance of the three additional exercises. At this appointment, and at the subsequent ones, which occurred on the $14^{\text {th }}, 45^{\text {th }}$, $75^{\text {th }}$ and $105^{\text {th }} \mathrm{PO}$, on dates and in location coincident with the routine medical follow-up appointments, measurements of the ROM of the shoulder were carried out, the patients were asked to demonstrate the exercises, the movements were corrected where necessary, and they were encouraged to continue the performance of the exercises at home. This structuring of the program aimed to maximize the adherence by the patients, which was measured at each evaluation, according to the self-report of the patient regarding the performance of the exercises in the domicile in the period immediately preceding the evaluation. The performance of exercises on five to seven days of the week, at least once a day, was considered satisfactory adherence, and a frequency equal to or less than four times a week considered unsatisfactory adherence.

All the analyses were carried out using SPSS ${ }^{\circledR}$ for Windows (version 11.5). With regard to the data analysis, the descriptive variables were summarized as number and percentage or as mean and standard deviation. For the ROM, mean profiles were constructed for each of the movements, according to the type of surgery and the length of recuperation, and inferential analysis of variance (ANOVA) with repeated measures (SAS v.9.2). The comparison between the two groups was performed using the Student's t-test or the MannWhitney test. Throughout the statistical analysis a significance level of $5 \%(p<0.05)$ was adopted.

\section{Results}

From August 2006 to June 2008, 64 women completed the monitoring for a minimum of 75 days. The demographic and clinical characteristics are summarized in Table 1, separated according to type of surgery.

Table 1 - Demographic and clinical variables of the patients with breast cancer undergoing surgical treatment in the São Paulo Hospital, SP, Brazil, 2008

\begin{tabular}{|c|c|c|c|c|c|}
\hline \multirow{2}{*}{ Variables } & \multicolumn{2}{|c|}{ Mastectomy } & \multicolumn{2}{|c|}{ Quadrantectomy } & \multirow{2}{*}{$p$-value } \\
\hline & $n=43$ & $(67 \%)$ & $\mathrm{n}=\mathbf{2 1}$ & $(33 \%)$ & \\
\hline Age, years & \multicolumn{2}{|c|}{$52.2 \pm 9.6$} & \multicolumn{2}{|c|}{$63.4 \pm 9.0$} & $<0.001$ \\
\hline Marital status & & & & & 0.234 \\
\hline Married & 19 & $(44.2 \%)$ & 8 & $(38.1 \%)$ & \\
\hline Single & 14 & $(32.5 \%)$ & 4 & $(19.0 \%)$ & \\
\hline Widowed & 4 & $(9.3 \%)$ & 6 & $(28.6 \%)$ & \\
\hline Divorced & 6 & $(14.0 \%)$ & 3 & $(14.3 \%)$ & \\
\hline \multicolumn{6}{|l|}{ Schooling } \\
\hline $\begin{array}{l}\text { Elementary } \\
\text { Education }\end{array}$ & 32 & $(74.4 \%)$ & 13 & $(61.9 \%)$ & \\
\hline $\begin{array}{l}\text { High School } \\
\text { Education }\end{array}$ & 9 & $(21.0 \%)$ & 5 & $(23.8 \%)$ & \\
\hline $\begin{array}{l}\text { Higher } \\
\text { Education }\end{array}$ & 2 & $(4.6 \%)$ & 3 & $(14.3 \%)$ & \\
\hline $\begin{array}{l}\text { Employment } \\
\text { status }\end{array}$ & & & & & 0.241 \\
\hline Retired & 4 & $(9.3 \%)$ & 6 & $(28.6 \%)$ & \\
\hline Housewife & 17 & $(39.5 \%)$ & 9 & $(42.9 \%)$ & \\
\hline $\begin{array}{l}\text { Remunerated } \\
\text { activity }\end{array}$ & 20 & $(46.5 \%)$ & 6 & $(28.6 \%)$ & \\
\hline On leave & 2 & $(4.7 \%)$ & 0 & $(0.0 \%)$ & \\
\hline Axillary dissection & & & & & $<0.001$ \\
\hline Yes & 38 & $(88.4 \%)$ & 10 & $(47.6 \%)$ & \\
\hline No & 5 & $(11.6 \%)$ & 11 & $(52.4 \%)$ & \\
\hline
\end{tabular}


With regard to the effectiveness of the program, in Table 2 the data are presented relative to variations in the ROM of flexion, abduction and extension beyond the midline of the shoulder ipsilateral to the surgery, separated according to type of surgery and length of monitoring.

Table 2 - Variations in the ROM (average) according to the time and the surgery of the breast cancer patients undergoing surgical treatment in the São Paulo Hospital, SP, Brazil, 2008

\begin{tabular}{|c|c|c|c|c|c|c|c|c|}
\hline $\begin{array}{l}\text { Shoulder } \\
\text { ROM }\end{array}$ & Surgery & Preoperative & $\begin{array}{c}1^{\text {st }} \\
\begin{array}{c}\text { Postoperative } \\
\text { day }\end{array} \\
\end{array}$ & $\begin{array}{c}7^{\text {th }} \\
\text { Postoperative } \\
\text { day }\end{array}$ & $\begin{array}{c}14^{\text {th }} \\
\text { Postoperative } \\
\text { day }\end{array}$ & $\begin{array}{c}4^{\text {th }} \\
\begin{array}{c}\text { Postoperative } \\
\text { day }\end{array} \\
\end{array}$ & $\begin{array}{c}7^{\text {th }} \\
\begin{array}{c}\text { Postoperative } \\
\text { day }\end{array} \\
\end{array}$ & $\begin{array}{c}105^{\text {th }} \\
\begin{array}{c}\text { Postoperative } \\
\text { day }\end{array} \\
\end{array}$ \\
\hline \multirow[t]{2}{*}{ Flexion } & Mastectomy & $175.8 \pm 0.9$ & $93.7 \pm 4.4^{*}$ & $107.1 \pm 3.6^{*}$ & $136.8 \pm 4.3^{*}$ & $150.7 \pm 3.9^{*}$ & $158.0 \pm 5.2^{*}$ & $167.2 \pm 2.6$ \\
\hline & Quadrantectomy & $176.6 \pm 0.9$ & $126.2 \pm 8.1^{*}$ & $145.8 \pm 6.7^{*}$ & $164.7 \pm 6.4$ & $166.1 \pm 4.6$ & $173.3 \pm 2.5$ & $176.6 \pm 1.6$ \\
\hline p-value & & 0.406 & $<0.001$ & $<0.001$ & 0.001 & 0.058 & 0.296 & 0.526 \\
\hline \multirow[t]{2}{*}{ Extension } & Mastectomy & $55.2 \pm 1.4$ & $41.6 \pm 1.6^{*}$ & $48.4 \pm 1.2^{*}$ & $52.7 \pm 1.5^{*}$ & $53.4 \pm 2.0$ & $56.4 \pm 2.0$ & $57.0 \pm 2.2$ \\
\hline & Quadrantectomy & $52.1 \pm 2.3$ & $42.9 \pm 2.8^{*}$ & $48.7 \pm 2.8$ & $55.0 \pm 4.1$ & $49.5 \pm 1.9$ & $55.2 \pm 2.5$ & $51.9 \pm 3.0$ \\
\hline$p$-value & & 0.247 & 0.583 & 0.675 & 0.378 & 0.799 & 0.306 & 0.470 \\
\hline \multirow[t]{2}{*}{ Abduction } & Mastectomy & $174.6 \pm 1.1$ & $84.5 \pm 4.2^{*}$ & $97.7 \pm 3.6^{*}$ & $118.6 \pm 5.6^{*}$ & $138.1 \pm 5.5^{*}$ & $150.8 \pm 6.6^{*}$ & $164.3 \pm 3.1^{*}$ \\
\hline & Quadrantectomy & $176.5 \pm 0.9$ & $110.5 \pm 6.3^{*}$ & $134.8 \pm 8.0^{*}$ & $162.9 \pm 5.5^{*}$ & $159.4 \pm 5.1^{*}$ & $167.8 \pm 3.2$ & $177.9 \pm 1.0$ \\
\hline$p$-value & & 0.647 & 0.002 & $<0.001$ & $<0.001$ & 0.006 & 0.195 & 0.189 \\
\hline
\end{tabular}

ROM = Range of motion

* p statistically significant $(p<0.05)$ when compared to the baseline measurement (preoperative)

According to the data in Table 2, it can be seen that the three movements evaluated in the $1^{\text {st }}$ PO presented a decrease in the mean values, when compared to the baseline measurement (preoperative), followed by a continuous increase from the $7^{\text {th }}$ until the $105^{\text {th }} \mathrm{PO}$, both in the women who underwent mastectomy and those who underwent quadrantectomy. The comparison between the means obtained at each evaluation showed different behavior in the flexion and abduction movements, in both types of surgery, over time, i.e. until the $14^{\text {th }} \mathrm{PO}$ for the flexion $(p=0.001)$ and until the $45^{\text {th }} \mathrm{PO}$ for the abduction $(p=0.006)$. In the women who underwent mastectomy, the final means of these movements were lower than those observed before surgery in all the evaluations (flexion: $p=0.526$; abduction: $p=0.044$ ). In the flexion movement, there was a statistically significant difference between the baseline measurement and the subsequent measurements until the $75^{\text {th }} \mathrm{PO}(\mathrm{p}<0.001)$, whereas in the abduction this difference remained until the final evaluation $(p=0.044)$. In the women that underwent quadrantectomy, the mean of these movements did not present a statistically significant difference when compared with the baseline measurement at the end of the monitoring (flexion: $p=0.890$; abduction: $p=0.721$ ). The flexion presented a statistically significant difference until the $7^{\text {th }} \mathrm{PO}(\mathrm{p}<0.001)$, whereas the abduction maintained this difference until the $45^{\text {th }} P O(p=0.014)$. The behavior of the extension did not present a statistically significant difference according to the type of surgery, however, in the women who underwent mastectomy, this movement proved to be recovered in the $45^{\text {th }} \mathrm{PO}$ evaluation $(\mathrm{p}=0.164)$, and in those who underwent quadrantectomy, from the $7^{\text {th }} P O(p=0.273)$.

Regarding the adherence to the program reported by the patients, the two surgical modalities presented similar behavior, with no statistically significant difference between the percentage of women who reported satisfactory adherence (performance of exercises equal to or greater than five times a week) and unsatisfactory adherence (performance of exercises less than five times a week) in each surgery group. Given this, the analysis of adherence is presented as a single group, shown in Figure 2.

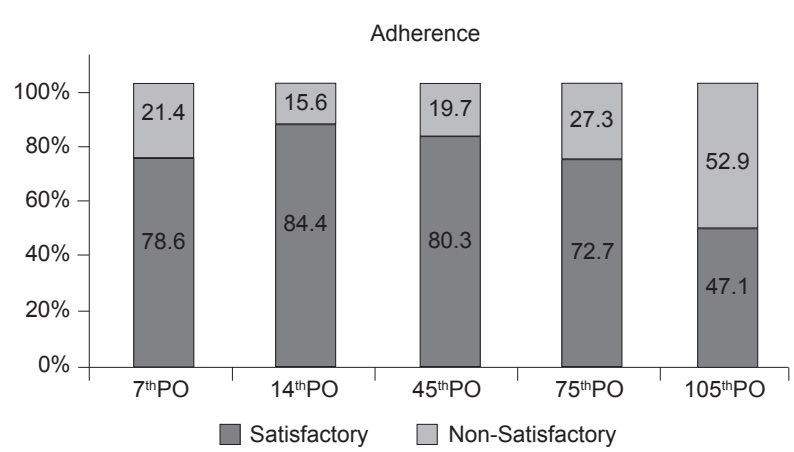

Figure 2 - Self-reported adherence to the post-operative exercise program according the evaluation, São Paulo, SP, Brazil, 2008

The analysis of adherence shows that satisfactory adherence from the $7^{\text {th }} \mathrm{PO}$ until the $75^{\text {th }} \mathrm{PO}$ varied from 
75.8 to $91.2 \%$. Furthermore, it was observed that the adherence declined according to the recuperation of the ROM. It should be noted that in the comparison between the group that completed the program and the group of follow-up losses, there was no significant difference with respect to mean age $(p=0.480)$, type of surgery $(p=0.556)$ or preoperative ROM (flexion: $p=0.071$; extension: $p=0.419$; abduction: $p=0.164$ ).

\section{Discussion}

The effectiveness of the exercise program was analyzed based on the functional recuperation of the ROM of the shoulder ipsilateral to the surgery, in the flexion, extension beyond the midline, and abduction movements. In women who underwent quadrantectomy, the recuperation of the movement of shoulder flexion was verified on the $14^{\text {th }} P O(164.7 \pm 6.4)$, and that of abduction on the $75^{\text {th }} \mathrm{PO}(167.8 \pm 3.2)$, when the mean values of these movements did not present a statistically significant difference with the baseline measurement (flexion: $p=0.059$; abduction: $p=0.143$ ). This result corresponds to the concept of functional recuperation ${ }^{(6,15)}$, which accepts a deficit of up to $10 \%$ of the initial ROM as rehabilitated movement. The recuperation time found was lower than that reported in other studies ${ }^{(2,6,12-15)}$. The rapid restoration of these movements can be attributed to the fact that this was a surgical modality with wedge resection of the breast containing the tumor and lateral margins of safety, greater conservation of the skin and without manipulation of the adjacent musculature(7), resulting in less loss of upper limb function. However, in the women who underwent mastectomy, these movements required more time for their recuperation. From a functional perspective, the last evaluation, both of the flexion and the abduction, presented a deficit of less than $10 \%$ of the initial value (flexion=167.2 \pm 2.6 ;


still presented a statistically significant difference when compared with the preoperative measurement $(p=0.044)$, whereas the flexion showed no significant difference $(p=0.079)$. These data are consistent with studies regarding time for recuperation of movement in women with breast cancer(11-12). The greater time for restoration of the functional ROM in women who underwent mastectomy may be explained by the extent of the surgery, performance of axillary lymphadenectomy and resection of one or two pectoral muscles in most cases, which culminates in the loss of upper limb function in the postoperative period, due to pain caused by the movement of this limb. Furthermore, the manipulation of the pectoral muscles and serratus anterior causes generalized loss of their functions, with losses to the flexion and abduction movements of the $\operatorname{arm}^{(7)}$. The extension movement, however, presented no loss after the surgery, being considered functionally recovered after the $7^{\text {th }} \mathrm{PO}$ in the women who underwent quadrantectomy $(p=0.272)$ and after the $45^{\text {th }} P O$ in the women who underwent mastectomy $(p=0.164)$. This data confirms the findings of researchers ${ }^{(14)}$, with respect to the time for recuperation, and shows a period less than that reported in other studies, which mention one to three months ${ }^{(2,12)}$. The rapid restoration of this movement is due to the fact that it occurs in the sagittal plane, after the return of the flexion movement, and corresponds to only 50 to 70 degrees of the amplitude of this plane beyond the midline.

Another aspect examined in the study was the adherence to the exercise program, which is little mentioned in the studies on rehabilitation after breast cancer surgery ${ }^{(12,15,17,20)}$. As mentioned, in these studies the form of evaluation is associated with attendance at the sessions, and does not include self-reports of the performance of the exercises in the home. Furthermore, these studies mentioned that adherence is higher in the initial postoperative periods, decreasing with each passing day, similar results to those found in the present study. The analysis of the adherence occurred from the self-reports of the patients, according to the weekly frequency of the performance of the exercises in the domiciles. Because there was no difference in the adherence according to the type of surgery, their analysis was carried out jointly. In the first two weeks, the vast majority of the patients reported satisfactory adherence to the program. However, from the $45^{\text {th }} \mathrm{PO}$, there was a gradual decrease in the percentage of patients who reported performing the exercises at least five days in the week, reaching $54.5 \%$ at the final evaluation, when the mean value of the ROM of the shoulder was already considered functionally recuperated. This fact can be explained by the sense of gradual improvement diminishing the perception of the need to perform the exercises. In addition, the characteristic of the program is also a determinant of its practice, where moderate activities are associated with lower levels of nonadherence compared to intense activities ${ }^{(17)}$.

As a practical implication, it may be noted that the implementation of an extramural program, structured to provide women the necessary conditions for the performance of the exercises in the domicile is feasible 
and effective for the functional recuperation of the upper limb. The low cost for the implementation of the program is highlighted, with benefits for women who, due to socio-economic characteristics, cannot attend a presential program. It is worth emphasizing the importance of the monitoring for at least 75 days for women who underwent quadrantectomy and 105 days for women who underwent mastectomy for the promotion of functional recuperation of the ROM, which involves the participation and support of the family and of the multidisciplinary team involved, in order to stimulate the adherence of these women to the implemented program. The main limitation of this study was the absence of a control group in order to compare the effectiveness of the extramural program with the outpatient modality. However, the results achieved, in terms of recuperation of the movements, were similar to those of studies performed in an outpatient setting, described in the literature ${ }^{(2,5-6,12-15,18)}$.

\section{Conclusion}

The results of this study showed that the number and type of exercises that constitute the extramural program were effective for the recuperation of the flexion, abduction and extension movements of the shoulder ipsilateral to the surgery in this population. The recuperation of these movements occurred at different moments of the program, from the $7^{\text {th }}$ to the $105^{\text {th }} \mathrm{PO}$, with the minimum monitoring after quadrantectomy being 75 days, and for mastectomy, 105 days. This confirms the benefit of early initiation of the functional rehabilitation, with continuous monitoring for at least three months after surgery. It is also considered that this program can benefit populations with similar characteristics to the one studied, that attend public health services.

\section{References}

1. Ministério da Saúde, INCA (BR) [Internet]. Estimativa 2010 - Incidência de câncer no Brasil. [acesso 10 abril 2010]. Disponível em: http://www1.inca.gov. br/estimativa/2010/index.asp?link=tabelaestados. asp\&UF $=B R$

2. Cinar N, Seckin Ü, Keskin D, Bodur H, Bozkurt B, Cengiz $O$. The effectiveness of early rehabilitation in patients with modified radical mastectomy. Cancer Nurs. 2008;31(2):160-5.
3. Kilgour RD, Jones DH, Keyserlingk JR. Effectiveness of a self-administered, home-based exercise rehabilitation program for a women following modified radical mastectomy and axillary node dissection: a preliminary study. Breast Cancer Res Treat. 2008;109(2):285-95.

4. Larsson IL, Jönsson C, Olsson AC, Gard G, Johansson K. Women's experience of physical activity following breast cancer treatment. Scand J Caring Sci. 2008;22:422-9.

5. Lauridsen MC, Christiansen P, Hessov IB. The effect of physiotherapy in shoulder function in patients surgically treated for breast cancer: a randomized study. Acta Oncol. 2005;44(5):449-57.

6. Rezende LF, Franco RL, Rezende MF, Beletti PO, Morais SS, Gurgel MS. Two exercises schemes in postoperative breast cancer: comparison of effects on shoulder movement and lymphatic disturbance. Tumori. 2006;92(1):55-61.

7. Harrington S, Padua D, Battaglini C, Michener LA, Giuliani C, Myers J, et al. Comparison of shoulder flexibility, strength, and function between breat cancer survivors and healthy participants. J Cancer Surv. 2011;5:167-74.

8. Shamley DR, Srinanaganathan R, Weatherall R, Oskrochi $\mathrm{R}$, Watson $\mathrm{M}$, Ostlere $\mathrm{S}$, et al. Changes in shoulder muscle size and activity following treatment for breast cancer. Breast Cancer Res Treat. 2007;106(1):19-27.

9. Springer BA, Levy E, McGarvey C, Pfalzer LA, Stout $\mathrm{NL}$, Gerbeer $\mathrm{LH}$, et al. Pre-operative assessment enables early diagnosis and recovery of shoulder function in patients with breast cancer. Breast Cancer Res Treat. 2010;120:135-47.

10. Baraúna MA, Canto RST, Schulz E, Silva RAV da; Silva CDC, Veras MT da S, et al. Avaliação da amplitude de movimento do ombro em mulheres mastectomizadas pela biofotogrametria computadorizada. Rev Bras Cancerol. 2004;50(1):27-31.

11. Bergmann A, Ribeiro MJP, Pedrosa E, Nogueira EA, Oliveira ACG. Fisioterapia em Mastologia: rotinas do Hospital do Câncer III/INCA. Rev Bras Cancerol. 2006;52(1):97-109.

12. Box RC, Reul-Hirche HM, Bullock-Saxton JE, Furnival CM. Shoulder movement after breast cancer surgery: results of a randomized controlled study of postoperative physiotherapy. Breast Cancer Res Treat. 2002;75:35-50.

13. Amaral MTP, Teixeira LC, Derchain SFM, Nogueira MD, Pinto e Silva MP, Gonçalves AV. Orientação domiciliar: proposta de reabilitação física para mulheres submetidas à cirurgia por câncer de mama. Rev Cienc Méd. (Campinas) 2005;14(5):405-13. 
14. Morimoto $T$, Tamura $A$, Ichihara $T$, Minakawa T, Kuwamura $Y$, Miki $Y$, et al. Evaluation of a new rehabilitation program for postoperative patients with breast cancer. Nurs Health Sci. 2003;5:275-82.

15. Pinto e Silva MP, Derchain SFM, Rezende L, Cabello C, Martinez EZ. Movimento do ombro após cirurgia por carcinoma invasor da mama: estudo randomizado prospectivo controlado de exercícios livres versus limitados a $90^{\circ}$ no pós-operatório. RBGO. 2004;26(2):125-30.

16. McNeely ML, Campbel K, Ospina M, Rowe BH, Dabbs $K$, Klassen TP, et al. Exercise interventions for upper-limb dysfunction due to breast cancer treatment (Review). Cochrane Database of Systematic Reviews 2010, Issue 10, Art no CD005211. DOI: 10.1002/14651858. CD005211.pub

17. Sant'Anna DK, Almeida V, Petito EL, Gutiérrez MGR. Adesão à prática de exercícios para reabilitação funcional de mulheres com câncer de mama: revisão de literatura. Cienc Enferm. 2010;16(1):97-104.

18. Rivero de Gutiérrez MG, Bravo MM, Chanes DC, Vivo MCR de, Souza GO de. Adherence to an early rehabilitation program among women who underwent mastectomy. Acta Paul Enferm. 2007;20(3):249-54.

19. World Health Organization-WHO. Meeting Report. Adherence to long-term therapies: policy for action. Geneva: 2003. [acesso 10 abril 2010]. Disponível em: http://apps.who.int/medicinedocs/en/d/Js4883e/

20. Prado MAS, Mamede MV, Almeida AM, Clapis MJ. A prática de atividade física em mulheres submetidas à cirurgia por câncer de mama: percepção de barreiras e benefícios. Rev. Latino-Am. Enfermagem. 2004;12(3):494-502.

21. Marques AP. Manual de goniometria. $2^{a}$ ed. São Paulo: Manole; 2003.

22. Silva G, Santos MA. Stressors in breast cancer posttreatment: a qualitative approach. Rev. Latino-Am. Enfermagem. 2010;18(4):688-95.

23. Petito EL, Gutiérrez MGR. Elaboração e validação de um programa de exercícios para mulheres submetidas à cirurgia oncológica de mama. Rev Bras Cancerol. 2008;54(3):275-87.

24. Pallás JMA, Villa JJ. Métodos de investigación clínica y epidemiológica. $2^{\text {aed. }}$ Madrid: Harcourt; 2000. 